Article

\title{
High-Efficiency Bioenergy Carbon Capture Integrating Chemical Looping Combustion with Oxygen Uncoupling and a Large Cogeneration Plant
}

\author{
Jussi Saari *(D), Petteri Peltola, Tero Tynjälä, Timo Hyppänen, Juha Kaikko ${ }^{(D)}$ and \\ Esa Vakkilainen $(D)$ \\ School of Energy Systems, Energy Technology, Lappeenranta-Lahti University of Technology LUT, \\ Yliopistonkatu 34, 53850 Lappeenranta, Finland; petteri.peltola@lut.fi (P.P.); tero.tynjala@lut.fi (T.T.); \\ timo.hyppanen@lut.fi (T.H.); juha.kaikko@lut.fi (J.K.); esa.vakkilainen@lut.fi (E.V.) \\ * Correspondence: saari@lut.fi; Tel.: +358-40-7765-897
}

Received: 7 May 2020; Accepted: 9 June 2020; Published: 14 June 2020

\begin{abstract}
Bioenergy with $\mathrm{CO}_{2}$ capture and storage (BECCS) is a promising negative emission technology (NET). When using sustainably produced biomass as fuel, BECCS allows the production of power and heat with negative $\mathrm{CO}_{2}$ emissions. The main technical challenges hindering the deployment of BECCS technologies include energy penalties associated with the capture process. This work evaluates the performance of an advanced $\mathrm{CO}_{2}$ capture technology, chemical looping with oxygen uncoupling (CLOU), in conjunction with biomass-fired combined heat and power (CHP) generation. Results from a MATLAB/Simulink reactor model were incorporated in a plant and integration model developed in a commercial process simulation software to quantify the key performance indicators of the CLOU-integrated CHP plant. Both energy and exergy analysis were conducted. The results show a remarkably low efficiency penalty of $0.7 \%$ compared to a conventional reference plant, and a high carbon capture efficiency of $97 \%$. The low efficiency penalty is due to the high moisture and hydrogen contents of the biomass, and the separation of combustion products and excess air streams in the CLOU process; these together provide an opportunity to recover a significant amount of heat by flue gas condensation at a higher temperature level than what is possible in a conventional boiler. The condensing heat recovery yields an $18 \mathrm{MW}$ generator power increase (3 MW loss in net power output) for the CLOU plant; in the reference plant with conventional boiler, the same scheme could achieve an increase of $9 \mathrm{MW}$ (generator) and a decrease of $8 \mathrm{MW}$ (net).
\end{abstract}

Keywords: BECCS; CLOU; CHP; cogeneration; flue gas condensation; process integration

\section{Introduction}

It appears likely that, to limit the atmospheric $\mathrm{CO}_{2}$ concentration to levels compatible even with the $2{ }^{\circ} \mathrm{C}$ warming goal, and particularly the $1.5^{\circ} \mathrm{C}$ goal, substantially net negative $\mathrm{CO}_{2}$ emission balance must be achieved by the second half of the century [1,2]. Among a variety of different negative emission technologies (NETs) to remove $\mathrm{CO}_{2}$ from the atmosphere, bioenergy with carbon capture and storage (BECCS) offers a promising combination of a carbon removal potential estimated at $0.5-5 \mathrm{Gt}_{\mathrm{CO} 2} /$ year and removal cost estimated at 100-200 USD/t $\mathrm{CO}_{2}$ [3]. The potential for BECCS has significant regional variation; it appears particularly attractive in the Nordic countries where the biomass potential per capita is among the highest in the world.

BECCS can be utilized in the power and heat industry, where CCS technology has been developed with the goal of curbing emissions from fossil fuel use. As the direct emission of $\mathrm{CO}_{2}$ from biomass combustion is similar to what the plant sequestered from the atmosphere during its growth, BECCS will 
result in net negative emissions, provided that an appropriate storage option is available for the captured $\mathrm{CO}_{2}$. The significant energy penalties and equipment costs usually associated with the capture process still hinder the feasibility of BECCS technologies for widespread use, however [4].

The main $\mathrm{CO}_{2}$ capture technologies are based on pre-combustion, oxy-combustion, or post-combustion. The large parasitic loads of these processes reduce the net power generation of a power plant considerably [5]. Chemical looping combustion (CLC), a technology allowing intrinsic separation of $\mathrm{CO}_{2}$ from the combustion process with a relatively low net efficiency penalty, is one promising concept proposed as a way to alleviate this problem [6]. The comparatively simple CLC process is also likely to offer lower additional equipment cost than what would be possible with most carbon capture technologies [7].

Existing CLC installations typically consist of two interconnected fluidized bed reactors: an air reactor (AR) and a fuel reactor (FR). A solid metallic oxide oxygen carrier circulates between the reactors. The concept has been demonstrated successfully for gaseous, liquid, and solid fuels; particularly, natural gas CLC applications have attracted much attention. In the FR, the fuel is oxidized, taking the oxygen from the solid oxygen carrier rather than from molecular oxygen in the air as happens in conventional combustion. After being reduced in the FR, the solid oxygen carrier is recirculated back to the AR, where it is re-oxidized with atmospheric air. The exhaust gas from the FR consists mainly of $\mathrm{CO}_{2}$ and $\mathrm{H}_{2} \mathrm{O}$. Ideally, the condensation of the water vapor leaves a $\mathrm{CO}_{2}$ stream ready for sequestration, allowing the capture of $\mathrm{CO}_{2}$ without any gas separation step, which normally constitutes the main cost of CCS [8].

With solid fuels, reactions between solid fuel and solid oxygen carrier would not take place at a useful rate [6]. One solution to this is an intermediate fuel gasification step to form syngas. In in-situ gasification CLC ( $i$ G-CLC), the fuel is fed into the FR, where it is first gasified to CO, $\mathrm{CH}_{4}$, and various other gaseous products, which then react with the solid oxygen carrier. The reaction rate of the entire process is limited by the gasification step, which can be up to 100 times slower than the combustion step [9]. Chemical looping with oxygen uncoupling (CLOU) represents a way of avoiding the rate-limiting gasification step, relying instead on the capability of some oxygen carriers to release the oxygen to gas phase at temperature levels useful for combustion $\left(800-1200^{\circ} \mathrm{C}\right)$ [10]. This way the solid fuel combustion takes place in an oxygen-rich atmosphere facilitating faster char conversion and oxygen carrier reduction, and thereby allowing smaller oxygen carrier inventories and smaller reactor dimensions [11,12]. The energy output from a CuO-based CLOU process using sawdust as fuel was recently determined to be $27 \%$ greater than that from a $\mathrm{Fe}_{2} \mathrm{O}_{3}$-based $i \mathrm{G}$-CLC process [13], demonstrating the benefits of oxygen carriers with CLOU properties in solid-fuel CLC-based CCS. Although early studies on solid-fuel CLOU mostly focused on fossil coal, biomass has recently attracted increasing attention; in addition to allowing the possibility of negative emission, biomass also has the additional advantage of higher reactivity.

CHP production combines the production of electricity and usable heat in the same plant. In separate production of electricity, much of the fuel energy must be discarded as waste heat, whereas in a CHP plant much or all of this can become a heat energy product. This allows a clear improvement in overall efficiency over separate stand-alone production. The heat is typically used either as steam in industrial processes, or as district heat $(\mathrm{DH})$, the latter usually sent to the customer in the form of $70-120^{\circ} \mathrm{C}$ water. Modern biomass-fired CHP plants typically achieve $75-90 \%$ overall efficiencies. Biomass-fired CHP production can thus represent a low-carbon, high-efficiency energy system in and of itself.

A CHP plant can also be equipped with a carbon capture process, but, depending on the carbon capture technology used and the temperature levels required for the heat, in a CHP plant, some of the energy lost in the carbon capture process can be recovered to augment heat production, resulting in efficiency and cost benefits. The combination of district heating and CLC-based biomass CCS implementation can be particularly advantageous in this respect: the fuel reactor gas stream has a high concentration of water due to the combination of fuel characteristics and lack of nitrogen and 
excess oxygen in the stream, while the DH network offers a large, relatively low-temperature heat sink to which the condensing heat can be recovered. In Finland, the potential for biomass-fired CHP CCS is significant; in 2017, 33\% of total electricity generation and $65 \%$ of district heat supply originated from CHP plants with forest wood the most common source of fuel [14].

The goal of this work is to evaluate the thermodynamic and technical potential of a next-generation biomass-fired CCS concept in a CHP context. This is performed by combining process simulation of a $\mathrm{CuO} / \mathrm{Cu}_{2} \mathrm{O}$-based CLOU process with a flowsheet model of a cogeneration plant producing electricity, district heat, and process steam for industry. The CLOU reactor model is based on earlier work performed at LUT University [11,15]. The CHP plant model is implemented using commercial process simulation software. A condensing heat recovery scheme based on the use of multi-stage packed bed scrubbers and heat pumps was designed for heat integration of the $\mathrm{CO}_{2}$ capture process, DH network, and the CHP plant steam cycle.

The key performance indicators such as power and heat outputs, energy and exergy efficiencies, auxiliary consumption, carbon capture rate, and specific $\mathrm{CO}_{2}$ emissions of the CLOU-integrated CHP plant are quantified and compared with those of a reference plant equipped with a conventional $C F B$ boiler without $\mathrm{CO}_{2}$ capture.

\section{Methods}

The study focuses on a large-scale biomass-fired CHP plant using Nordic forest wood biomass as fuel, with a lower heating value of $\mathrm{LHV}_{\mathrm{d}}=19.5 \mathrm{MJ} / \mathrm{kg}$ for the dry fraction, $8.53 \mathrm{MJ} / \mathrm{kg}$ as fired ( $50 \%$ wet-basis moisture). The plant configuration is based on an actual operating one. The reference case model, equipped with a conventional CFB boiler, was designed to replicate the actual plant as closely as available data allow. This is then used as the basis for the CLOU plant model. The CLOU plant has identical heat production with the reference plant: $110 \mathrm{MW}$ district heat, $40 \mathrm{MW} 10 \mathrm{bar}(\mathrm{a})$ high pressure steam, and $90 \mathrm{MW} 4.5 \mathrm{bar}(\mathrm{a})$ low pressure steam. The same fuel input is also maintained, at $430 \mathrm{MW}_{\mathrm{LHV}}$, and power generation is allowed vary.

The CHP plant and integration modeling were implemented using IPSEpro process simulation software by SimTech, version 7. IPSEpro is an equation-oriented process simulation tool widely used for power plant simulation; it has been used for modeling chemical looping CCS systems [16], and the authors have also used it for numerous studies investigating various aspects of biomass-fired CHP plant optimization [17] and process integration [18]. The standard module library of IPSEpro includes the majority of typical power plant components, and additional modules can be created with a module development kit.

The CLOU reactors were modeled separately from the main IPSEpro plant model, using a core-annulus type fluidized bed model. The model is based on mass and energy balances, as well as semi-empirical heat transfer, fluid dynamics, and chemical reaction models. The reactor model was developed earlier in MATLAB/Simulink environment, and is described in more detail in $[11,15]$. For the IPSEpro CHP plant model, a CLOU reactor system module was created in the module development kit. The reactor module takes as manual input CLOU reactor simulation results, and gives out exiting gas stream sources matching said results.

\subsection{Performance Metrics}

The simulation results were used to determine the main plant performance indicators in terms of both carbon capture effectiveness and performance penalty compared to the reference plant. Based on the first law of thermodynamics, the net energy efficiency $\eta_{\text {net }}$ of the plant is

$$
\eta_{\text {net }}=\frac{P_{\mathrm{el}, \mathrm{net}}+\Phi_{\mathrm{DH}}+\Phi_{\text {steam }}}{\dot{m}_{\mathrm{f}} L H V_{\mathrm{f}}}
$$


where $P_{\mathrm{el}, \text { net }}(\mathrm{MW})$ is the net electrical output after deducting the auxiliary consumption $P_{\text {el,aux }}$ from the generator power $P_{\text {el,gen }}, \Phi_{\mathrm{DH}}(\mathrm{MW})$ is the district heat production, $\Phi_{\text {steam }}(\mathrm{MW})$ is the steam production, $\dot{m}_{\mathrm{f}}(\mathrm{kg} / \mathrm{s})$ is the fuel feed rate, and $L H V_{\mathrm{f}}(\mathrm{MJ} / \mathrm{kg})$ is the lower heating value of the fuel.

The first law analysis allows a simple comparison between $\mathrm{CO}_{2}$ capture plants or against a conventional reference plant to assess the efficiency penalty due to carbon capture. The shortcoming of first law analysis is that it fails to differentiate between the values of the electricity and heat, treating both as additive properties with the same relative value. In practice, they are not interchangeable: electricity can be easily converted to heat without significant losses, but the reverse is not true. Moreover, the first law analysis cannot be regarded as generic because the $\mathrm{CO}_{2}$ option assessment depends strongly on the selection of the process specifications of each unit operation, and fundamental improvements to the unit operations cannot be made without examining their thermodynamic limitations [19]. A second law analysis (exergy analysis) was thus also conducted.

Exergy measures also the quality of energy. An exergy analysis allows identifying thermodynamic inefficiencies and has been used to evaluate the performances and integration potentials of various energy conversion processes, including CLC [20] and CLOU [21]. For a unit, the irreversibilities I can be calculated through the exergy balance:

$$
I=E x_{\text {in }}-E x_{\text {out }}
$$

where $E x_{\text {in }}$ and $E x_{\text {out }}$ are the total exergy flows into and out of the system, including both the thermomechanical exergy and chemical exergy of the material streams as well as exergy associated with heat transfer. The exergy efficiency of the CHP plant $\varphi$ is defined as

$$
\varphi=\frac{E x_{\mathrm{p}}}{E x_{\mathrm{f}}}
$$

where $E x_{\mathrm{p}}$ is the exergy of the products and $E x_{\mathrm{f}}$ is the exergy of the fuel input. The exergy in the exhaust gas stream is unrecoverable and excluded from the product exergy. Instead, the captured $\mathrm{CO}_{2}$ is a valuable product as a source of negative emissions or raw material for products with higher economic value (e.g., biofuels or plastics). In the results, the exergetic performance of CLOU plant is given for both cases, including and excluding the exergy value of $\mathrm{CO}_{2}$, and compared to exergetic efficiencies of the reference plants.

The CLOU process performance can be evaluated using the $\mathrm{CO}_{2}$ capture efficiency $\eta_{\mathrm{CC}}$, defined as the fraction of the fuel carbon captured from the fuel reactor gas stream:

$$
\eta_{\mathrm{CC}}=1-\left[\frac{[\mathrm{C}]_{\mathrm{char}}}{[\mathrm{C}]}\left(1-\mathrm{X}_{\mathrm{char}}\right)\right]
$$

where $[C]_{\text {char }}$ is the carbon mass fraction in the char, $[C]$ is the total carbon in the fuel, and $X_{\text {char }}$ is the conversion of char in the fuel reactor,

$$
X_{\mathrm{char}}=1-\frac{\dot{m}_{\mathrm{char}, \mathrm{AR}}}{\dot{m}_{\mathrm{char}, \mathrm{in}}}
$$

where $\dot{m}_{\text {char,in }}$ is the char flow with the fuel and $\dot{m}_{\text {char,AR }}$ is the char flow rate into the air reactor. The specific $\mathrm{CO}_{2}$ emissions $\left(\mathrm{CO}_{2}\right.$ intensity) $S E_{\mathrm{CO}_{2}}$ is the ratio of $\mathrm{CO}_{2}$ emission to the atmosphere relative to the plant net power and heat generation:

$$
S E_{\mathrm{CO}_{2}}=\frac{\dot{m}_{\mathrm{CO}_{2}, \text { emitted }}}{P_{\mathrm{el}, \text { net }}+\Phi_{\mathrm{DH}}+\Phi_{\text {steam }}},
$$




\subsection{CLOU Reactors and Modeling}

An important factor in a CLC system is the choice of oxygen carrier. There is a limited selection of possible metal oxides having suitable equilibrium partial pressures of oxygen at temperature levels relevant for combustion to facilitate releasing oxygen in the fuel reactor. Of these, copper oxide, $\mathrm{CuO} / \mathrm{Cu}_{2} \mathrm{O}$ has received interest due to its high reactivity and oxygen transport capacity, and lack of thermodynamic limitations for complete hydrocarbon combustion. For these reasons, $\mathrm{CuO} / \mathrm{Cu}_{2} \mathrm{O}$ oxygen carrier was considered in this work, as a 50:50 mixture of active $\mathrm{CuO} / \mathrm{Cu}_{2} \mathrm{O}$ and supporting $\mathrm{TiO}_{2}$, with physical properties representing Geldart B particles (100-micron average particle size, $4650 \mathrm{~kg} / \mathrm{m}^{3}$ apparent density). In the CLOU regime, the oxygen carrier cycles between the $\mathrm{CuO}$ and $\mathrm{Cu}_{2} \mathrm{O}$ states,

$$
4 \mathrm{CuO} \leftrightarrow 2 \mathrm{Cu}_{2} \mathrm{O}+\mathrm{O}_{2}, \Delta H_{850}=263.2 \mathrm{~kJ} / \mathrm{mol}_{\mathrm{O} 2},
$$

where $\Delta H_{850}$ is the reaction enthalpy at $850^{\circ} \mathrm{C}$.

In the fuel reactor, the $\mathrm{CuO}$ releases oxygen in an endothermic reaction. The biomass undergoes devolatilization and combustion takes place with this gaseous oxygen, for a net exothermic process in the fuel reactor. The oxygen carrier is then transferred in its reduced form $\mathrm{Cu}_{2} \mathrm{O}$ to the air reactor, where is re-oxidized back to $\mathrm{CuO}$ in an exothermic reaction.

The oxidation and decomposition of the oxygen carrier are both affected by a thermodynamic driving force, which is governed by the difference between the partial pressure of oxygen in a reactor, $p_{\mathrm{O}_{2}}$, and the equilibrium $p_{\mathrm{O}_{2}}$. The equilibrium curve for a $\mathrm{CuO} / \mathrm{Cu}_{2} \mathrm{O}$ system is shown in Figure 1 . A detailed description of the oxygen carrier redox model used in this work is found in [12]. For both $\mathrm{CuO}$ reduction and $\mathrm{Cu}_{2} \mathrm{O}$ oxidation, a conversion rate equation can be formulated as

$$
r=f(T) f(X) f\left(p_{\mathrm{O}_{2}, \mathrm{eq}}\right),
$$

where $f\left(p_{\mathrm{O}_{2}, \text { eq. }}\right)$ represents the role of the thermodynamic driving force, $f(X)$ accounts for the reaction mechanism, and $f(T)$ expresses an Arrhenius-type dependency on temperature. The OC oxidation and reduction kinetics as applied in the air and fuel reactor models are shown in Table 1.

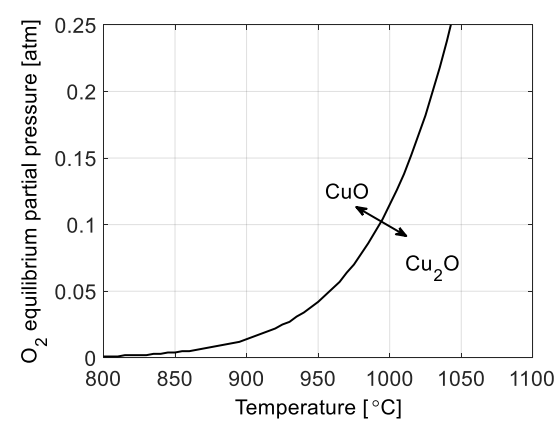

Figure 1. Equilibrium partial pressure of oxygen over the $\mathrm{CuO} / \mathrm{Cu}_{2} \mathrm{O}$ system.

\begin{tabular}{|c|c|c|}
\hline Item & Oxidation [22] (Air Reactor) & Reduction [23] (Fuel Reactor) \\
\hline$f(X)(-)$ & $1-X_{\mathrm{OC}}$ & $X_{\mathrm{OC}}$ \\
\hline$f\left(p_{\mathrm{O}_{2}, \text { eq. }}\right)\left(\mathrm{atm}^{1.3}\right)$ & $\left(p_{\mathrm{O}_{2}}^{\beta}-p_{\mathrm{O}_{2}, \mathrm{eq}}^{\beta}\right)$ & $\left(p_{\mathrm{O}_{2}, \mathrm{eq}}^{\beta}-p_{\mathrm{O}_{2}}^{\beta}\right)$ \\
\hline$f(T)\left(1 /\left(\mathrm{atm}^{1.3} \mathrm{~s}\right)\right.$ & $k_{1} e^{\frac{-k_{2}}{R_{\mathrm{u}} T}} *$ & $k_{1} e^{\frac{-k_{2}}{R_{\mathrm{u}} T}} *$ \\
\hline$p_{\mathrm{O}_{2} \text {,eq. }}(\mathrm{atm})$ & $6.057 \times 10^{-11} \cdot e^{0.02146 T * *}$ & $6.057 \times 10^{-11} \cdot e^{0.02146 T * *}$ \\
\hline$k_{1}\left(1 /\left(\operatorname{atm}^{1.3} \mathrm{~s}\right)\right)$ & $5.60 \times 10^{4}$ & $4.15 \times 10^{4}$ \\
\hline$k_{2}(\mathrm{~J} / \mathrm{mol})$ & $6.8 \times 10^{4}$ & $6.7 \times 10^{4}$ \\
\hline$\beta(-)$ & 1.3 & 1.3 \\
\hline
\end{tabular}

Table 1. Functions and constant parameters of oxygen carrier oxidation and reduction kinetics. 
Reactor performance has a significant impact on plant performance: a fuel conversion reduction of $2 \%$ typically reduces the $\eta_{\text {net }}$ of the plant by $1 \%$ [24]. The procedure to determine the reactor characteristics and operating conditions in this study is mostly similar to that presented in [12]; however, a full optimization of the reactor design was considered premature at this stage for the scope of the work. The main parameters at design-point operation are summarized in Table 2.

Table 2. Main design and operational parameters.

\begin{tabular}{lcc}
\hline \multicolumn{1}{c}{ Parameter } & Air Reactor & Fuel Reactor \\
\hline Height $(\mathrm{m})$ & 34 & 28 \\
Freeboard cross-section $\left(\mathrm{m}^{2}\right)$ & 84.6 & 72.2 \\
Target gas velocity $(\mathrm{m} / \mathrm{s})$ & $5-6.5$ & $5-6.5$ \\
Target average temperature $\left({ }^{\circ} \mathrm{C}\right)$ & 910 & 910 \\
Air-to-fuel ratio $(-)$ & 1.15 & $n / a$ \\
Airflow in $(\mathrm{kg} / \mathrm{s})$ & 171.9 & $n / a$ \\
Air temperature $\left({ }^{\circ} \mathrm{C}\right)$ & 282 & $n / a$ \\
Fuel input $(\mathrm{kg} / \mathrm{s})$ & $n / a$ & 50.4 \\
Recycle gas ratio $(-)$ & $n / a$ & 0.31 \\
Recycle gas input $(\mathrm{kg} / \mathrm{s})$ & $n / a$ & 40 \\
\hline
\end{tabular}

The CLOU reactor system employed in this work is shown in Figure 2. It consists of an oxidizer (air reactor, AR) and a reducer (fuel reactor, FR), both designed as atmospheric CFBs. Compared to other configurations, this design has many advantages [25]. Both the AR and the FR are operated in the fast fluidization regime, enabling gas-solids contact throughout the reactor height for maximum fuel conversion. The AR is fluidized with pre-heated air and the FR with partially recirculated flue gas. The FR gas wet basis recirculation ratio is defined as

$$
\phi_{\mathrm{fg}}=\frac{\dot{m}_{\mathrm{rec}}}{\dot{m}_{\mathrm{FR}, \text { out }}}
$$

where $\dot{m}_{\text {rec }}$ is the recirculation mass flow rate and $\dot{m}_{\mathrm{FR}, \text { out }}$ is the total exit flow from the fuel reactor. The formation of combustion gases along the reactor height also affects the appropriate choice of the recirculation ratio. A recirculation gas input of $40 \mathrm{~kg} / \mathrm{s}$, resulting in $\phi_{\mathrm{fg}}=0.31$, was considered. The recirculation gas is cooled to $450{ }^{\circ} \mathrm{C}$ or less prior to being returned to the FR. The cross-sectional areas of the reactors were sized so as to obtain desired gas velocities.

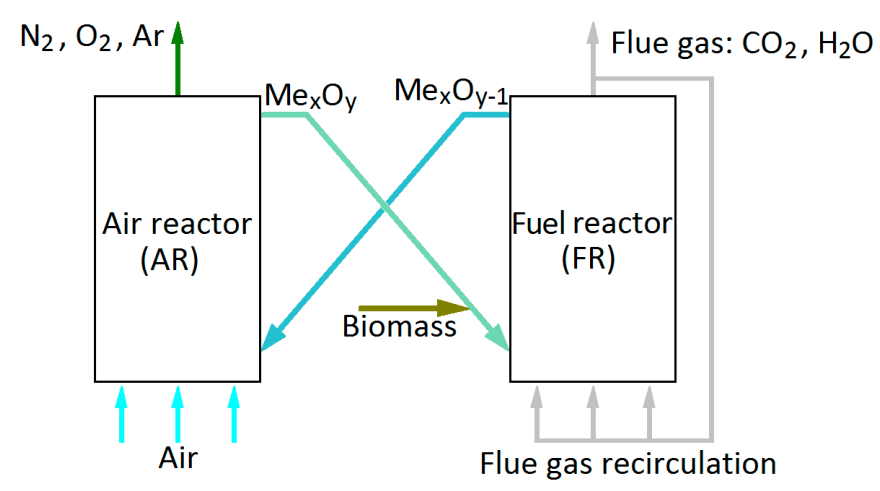

Figure 2. Schematic drawing of the CLOU reactor system.

The reaction kinetics and the equilibrium $p_{\mathrm{O}_{2}}$ depend heavily on temperature; the operating temperatures of the reactors are thus important. Temperatures of $900-950{ }^{\circ} \mathrm{C}$ have been identified as suitable for CuO-based oxygen carriers [26]. At typical CLC/CLOU operating conditions, approximately half of the fuel energy input is extracted from the reactors themselves [27]. The height of the reactors is 
determined by the heat transfer area required for cooling, as well as ensuring that there is space on the side wall for the particle separator and return systems.

To reduce fan power consumption and the reactor size, the bed material quantity in each reactor should be minimized. The oxygen carrier loading needed for effective combustion depends on the $\mathrm{CuO}$ reduction, $\mathrm{Cu}_{2} \mathrm{O}$ oxidation and fuel combustion kinetics. In the current case, a total solids loading of $460 \mathrm{~kg} / \mathrm{MW}_{\text {th }}$ was considered sufficient for $>95 \%$ fuel conversion [11,12]. A carbon stripper to remove unreacted char from the solids stream from FR to AR was considered unnecessary: the reactivity of biomass char particles allows $\mathrm{CO}_{2}$ capture efficiencies of over $95 \%$ [28].

The ash from the combustion must be purged periodically to avoid accumulation in the reactor system, although some oxygen carrier will be lost in the process. An excessive accumulation of the ash in circulating oxygen carrier can be prevented by a proper cyclone design and by employing other particle separation techniques [29]. In the current layout, $50 \%$ of the ash that accumulates in the solids stream is removed after the air reactor, assuming that the purge stream consists of $99 \%$ of ash and $1 \%$ of oxygen carrier. With this high selectivity toward ash, the oxygen carrier and ash purge/make-up flows have a negligible effect on the total material and energy balances, as shown in [12]. At this point, the assumptions regarding the disposal of ash and separation of oxygen carrier particles from the ash are somewhat tentative, and the topic represents a future research need for CLC/CLOU systems.

The behavior and performance of the suggested dual-fluidized bed CLOU system is evaluated using a 1.5D model applicable to chemical looping processes. The models are based on mass and energy balances, using semi-empirical correlations to evaluate the gas-solid fluid dynamics, heat transfer, and chemical reactions [11,12]. Data specific to the process (reactor cooling rates as well as flow rates, temperatures, and compositions of the exiting gas flows) can then be obtained and used in the CLOU plant model to determine the plant performance.

\subsection{Plant Configurations and Modeling}

Figure 3a depicts the reference plant and Figure $3 b$ the CLOU plant. The turbine is divided into three parts on a single shaft. After expansion in the high-pressure (HP) part, equipped with a partial-admission regulating stage, the remaining steam is split between a DH turbine with two $\mathrm{DH}$ condensers in series, and a condensing turbine. Both plants are modeled with IPSEpro process simulation software, but, in the CLOU plant, a reactor module takes as manual input the data obtained from MATLAB/Simulink CLOU reactor model.

Both plants take $430 \mathrm{MW}_{\mathrm{LHV}}$ fuel input and have steam values of $550{ }^{\circ} \mathrm{C}$ and 110 bar at turbine inlet, producing $110 \mathrm{MW}$ of district heat, $40 \mathrm{MW}$ of $10 \mathrm{bar}(\mathrm{a}) \mathrm{HP}$ steam, and $90 \mathrm{MW} 4.5 \mathrm{bar}(\mathrm{a})$ LP steam. Condensate returns from steam consumers at $60^{\circ} \mathrm{C}$; there is a combined total of $8 \mathrm{~kg} / \mathrm{s}$ condensate loss from HP and LP steam usages. The CLOU plant has the same fuel input and same heat loads as the reference plant.

The principal differences between the reference and the CLOU plant are the more complex back pass heat recovery scheme needed in the CLOU plant, and the opportunity to produce much of the $\mathrm{DH}$ by condensing the water vapor from the FR gas flow in the CLOU plant to separate it from the $\mathrm{CO}_{2}$. This will affect the sizing of the two parallel low-pressure turbines; the condensing one would be relatively larger and DH turbine smaller in the CLOU plant. The details of the condensing heat recovery scheme, omitted for space and clarity in Figure 3, are described later in Section 2.3.3.

\subsubsection{Steam Cycle}

The turbines are modeled similarly as described in [30]. The turbine module dry isentropic efficiencies at optimum flow rate are estimated to range from $87 \%$ (first HP module) to $92 \%$ (LP end of condensing and DH turbines). For the regulating stage, the optimum efficiency is $75 \%$. The pressure levels are estimated using the ellipse law; efficiency variation is estimated using correlations based on steam flow rate. 
The condensing turbine and DH turbine of the reference plant have swallowing capacities of 21 and $51 \mathrm{~kg} / \mathrm{s}$, respectively; as all turbines are on the same shaft and thus constantly turning, a small minimum cooling flow is always required in both turbines. CLOU plant condensing and DH turbine sizing is based on the $\mathrm{DH}$ production obtained from the condensing heat recovery scheme.

Both plants have a deaerator operating as an open feed heater at $4.2 \mathrm{bar}(\mathrm{a})$, and also two closed high-pressure heaters using approximately 10 and 16.5 bar(a) steam to heat the boiler feedwater to slightly over $200^{\circ} \mathrm{C}$.

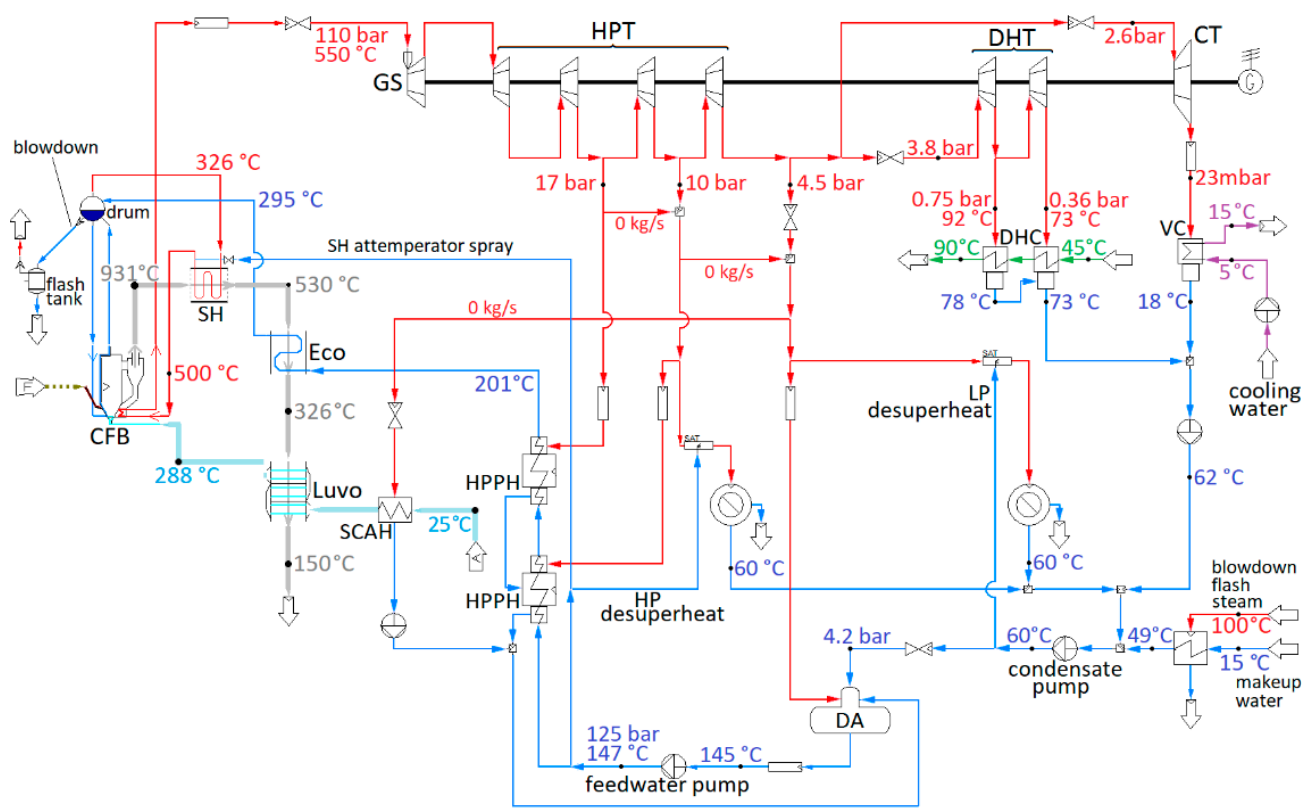

(a)

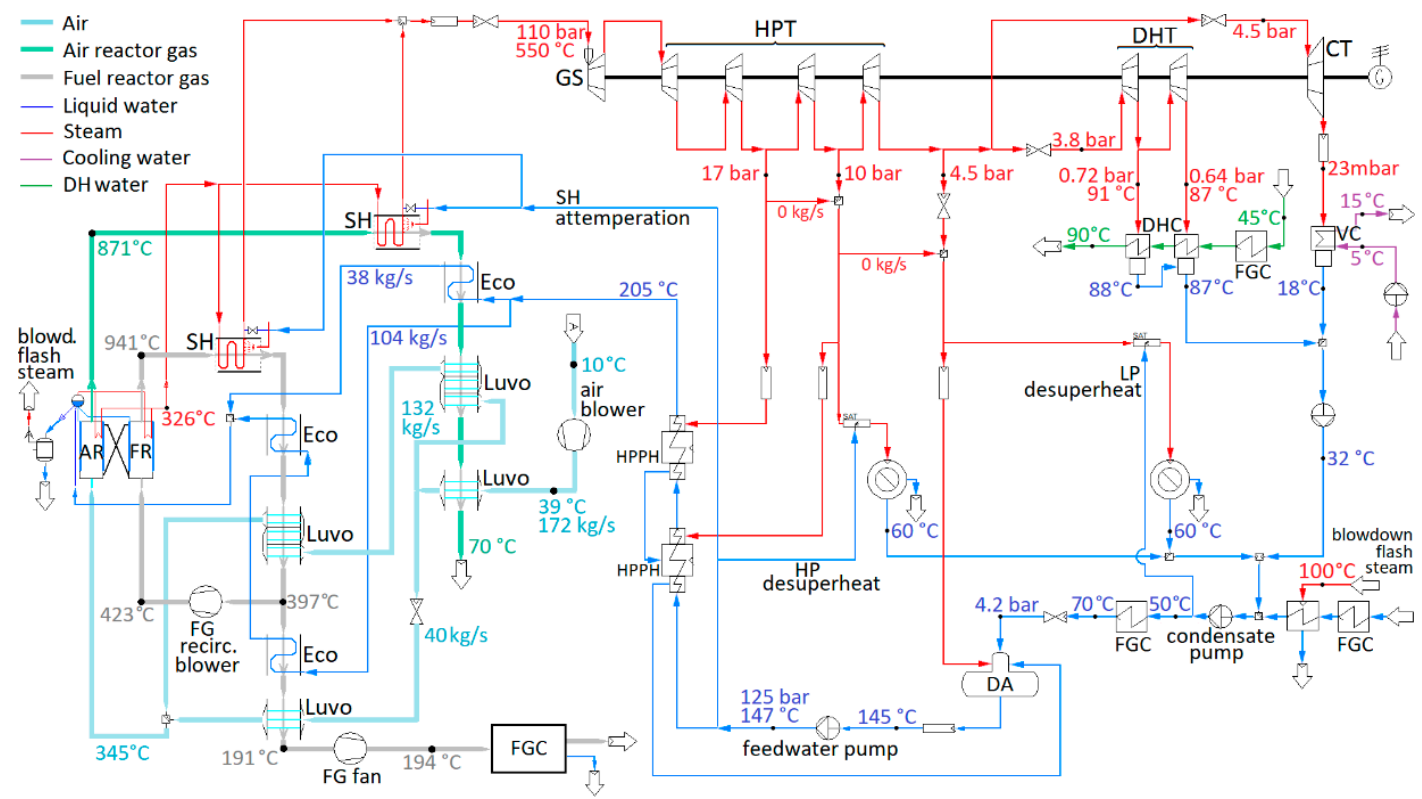

(b)

Figure 3. Configurations of: (a) the reference plant; and (b) the CLOU-CHP plant. Component labels: GS, governing stage; HPT, high pressure turbine; DHT, district heat turbine; $\mathrm{CT}$, condensing turbine; VC, vacuum condenser; DHC, district heat condensers; SH, Superheater; Eco, economizer; Luvo, air heater; SCAH, steam coil air heater; DA, deaerator; HPPH, high pressure feed preheater; FGC, flue gas condensers and the heat exchangers for heat recovery from condensate. 


\subsubsection{Boiler}

The reference plant CFB boiler is modeled with four main modules. The furnace module contains a simple steam generator heat transfer model based on an average furnace temperature and heat transfer coefficient, according to Basu [31]. All boiler losses except for the stack loss are also determined in the furnace module. The superheater, economizer and air preheater are each represented by a single heat exchanger component. A steam coil air heater (SCAH) is present so that a stack temperature sufficient to prevent acid condensation can always be maintained. One percent of the feedwater flow rate is removed as blowdown from the drum. The blowdown is depressurized, and flash steam is used to heat the makeup water.

In the IPSEpro CLOU plant model, the CFB furnace module is replaced with a CLOU reactor module, which takes the results of the separate CLOU reactor simulation as manual input, and gives out the gas streams of specified composition, state, and flow rate. The steam generator and superheater surfaces located in the air and fuel reactors are considered by specifying the cooling rates, obtained as output of the reactor model, into the IPSEpro plant model's reactor module.

The back pass heat transfer surfaces are designed so as to obtain the same live steam parameters, broadly similar temperature approach to the drum and combustion air temperatures as in the baseline $\mathrm{CHP}$ plant. The fuel reactor requires some flue gas to be recirculated. To permit affordable materials in the recirculation fan, the recirculation temperature can be no greater than $450{ }^{\circ} \mathrm{C}$. Satisfying these requirements required a somewhat more complex interconnected configuration of heat transfer surfaces, as seen in Figure 3.

Having two separate gas streams, of which one is almost completely devoid of chlorine and water, while the other one must have the water vapor mostly condensed for $\mathrm{CO}_{2}$ purification purposes, yields opportunities for improved heat recovery and thus efficiency. It was assumed that the stack temperature for the gas from the air reactor could be safely reduced to $70{ }^{\circ} \mathrm{C}$ without significant corrosion risk while still using inexpensive materials. In the flue gas stream from the fuel reactor, the exit temperature from the last conventional heat transfer surface, the last luvo stage, was increased to $195^{\circ} \mathrm{C}$ compared to the $150{ }^{\circ} \mathrm{C}$ stack temperature of the baseline $\mathrm{CHP}$ plant.

\subsubsection{Fuel Reactor Gas Water Removal and Heat Recovery}

To purify and compress the $\mathrm{CO}_{2}$ from the fuel reactor gas stream, the water vapor must be first removed by condensation. Compared to fossil coal, the moisture and hydrogen contents of biomass are high, resulting in a high partial pressure of water in the flue gas stream; in this case, $62 \mathrm{kPa}$ partial pressure of the flue gas ( $44 \%$ mass fraction). While the large amount of water condensation increases the size and cost of the equipment, the high partial pressure and thus condensation temperature also allows easier utilization of the latent heat of condensation for improved efficiency. DH water is used as the main heat sink in the flue gas condensers.

A condensing heat recovery scheme for a boiler can be implemented either as surface condensers or spray towers (scrubbers). In this work, a heat recovery scheme based on spray towers is considered. A typical configuration of such includes two different types of component, each with different functions: a packed-bed heat recovery scrubber (HRS), and a venturi scrubber (VS).

The configuration of a two-stage condensing heat recovery scheme is shown in Figure 4. The heat recovery takes place in the counter-flow HRS, where cold water is sprayed from above on a flue gas stream flowing up. A packed bed of filler elements provides an increased contact area for water and gas. Moisture in the flue gas condenses on the spray droplets and on the water pellicle formed on the bed filler elements.

The co-flow VS is located before the HRS (Figure 4). The temperature of the gas entering the VS is far above the dew point, and also too high to permit low-cost light-weight materials for the packed bed to be used in the HRS. By spraying water taken from the bottom of the HRS into the gas stream, evaporation rather than condensation will take place. The gas is cooled, and while the mass flow rate increases, the volumetric flow rate is considerably reduced. Although evaporation transfers heat to 
the gas rather than from it, the overall efficiency is not reduced: the heat will be recovered through condensation in the HRS. The VS can also serve as the final gas cleaning stage, and $\mathrm{pH}$ control can take place by $\mathrm{NaOH}$ injection.

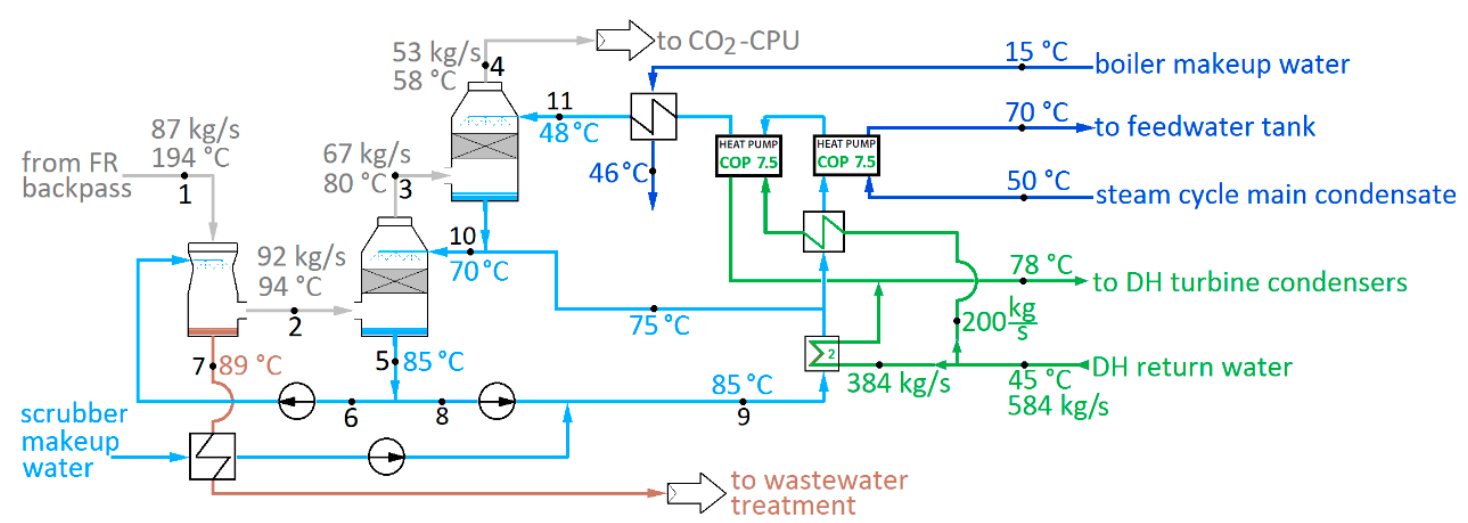

Figure 4. Heat recovery scheme with gas (1) entering a venturi scrubber (VS) at $194{ }^{\circ} \mathrm{C}$. Cooled flue gas (2) at increased moisture enters the sequential packed bed scrubbers (HRS), exits the first one at (3), and from the final one to the stack at reduced moisture and temperature (4). Liquid water (5) from the HRS is used for VS spray (6) and heat consumers (8). Water from VS (7) is sent to waterwater treatment after heat recovery to makeup water which is mixed into the stream to heat consumers (9). Cooled water (10 and 11) is used as spray water for both of the HRS. Grey streams are gas, light blue scrubber circulating water, dark blue boiler water, green $\mathrm{DH}$ water, and brown wastewater.

The spray water mass flow rate in the VS is typically much less than in the HRS, and dew point temperature is unlikely to be reached. A flue gas exit temperature $T_{2}=T_{\text {sat }}+5{ }^{\circ} \mathrm{C}$ is assumed here, with spray mass flow rate of $\dot{m}_{6}=60 \mathrm{~kg} / \mathrm{s}$.

The water outlet temperature $T_{7}$ from the VS is typically very close to the wet bulb temperature $T_{\mathrm{wb}}$ [32]. $T_{\mathrm{wb}}$ is found by applying the analogy of heat and mass transfer, yielding a well-known equation

$$
T_{\mathrm{wb}}=T_{\mathrm{g}}-\frac{M_{\mathrm{H}_{2} \mathrm{O}}}{\rho_{\mathrm{g}} c_{\mathrm{p}, \mathrm{g}}} \cdot \frac{p_{\mathrm{g}}}{R_{\mathrm{u}} T_{\mathrm{g}}} \cdot L e^{1-\mathrm{n}} \cdot h_{\mathrm{fg}}\left(T_{\mathrm{wb}}\right) \cdot \ln \frac{p_{\mathrm{g}}-p_{\mathrm{H}_{2} \mathrm{O}}}{p_{\mathrm{g}}-p_{\mathrm{sat}}\left(T_{\mathrm{wb}}\right)}
$$

where $R_{\mathrm{u}}$ is the universal gas constant, $T$ the absolute temperature $(\mathrm{K}), h_{\mathrm{fg}}$ the latent heat of evaporation, subscripts $g$ and $\mathrm{H}_{2} \mathrm{O}$ refer to mean wet flue gas conditions and water, respectively, and $L e$ is the Lewis number,

$$
L e=\frac{k_{\mathrm{g}}}{\rho_{\mathrm{g}} c_{\mathrm{p}, \mathrm{g}} D_{\mathrm{AB}}},
$$

where $D_{\mathrm{AB}}$ is the binary diffusion coefficient between water vapor and wet flue gas $\left(\mathrm{m}^{2} / \mathrm{s}\right)$ and $\mathrm{k}_{\mathrm{g}}$ is the thermal conductivity of wet flue gas $(\mathrm{W} / \mathrm{mK})$. Flue gas properties are determined as mass-weighted sums of the properties of its components evaluated at film temperature. With the preceding assumptions and equations, and applying mass and energy balances, the flue gas exit temperature and moisture content are found.

The spray water flow in the HRS is much greater than in the VS. The main mode of operation is condensation; relative moisture of the gas at exit is approximately $100 \%$. The temperature difference $\Delta T_{\mathrm{g}}$ of exiting flue gas flow to spray water can be affected by water flow rate and bed sizing. Optimal flow depends on the cost of packing material and desired flue gas outlet temperature. Detailed component design was ruled beyond the scope of this work; a value of $\Delta T_{\mathrm{g}}=10^{\circ} \mathrm{C}$ was considered typical for large-scale equipment and used for both $T_{4}-T_{11}$ and $T_{3}-T_{10}$ (see Figure 4 ). The heat exchangers in the scrubbing water cycle are assumed to be plate heat exchangers, dimensioned for $2{ }^{\circ} \mathrm{C}$ terminal temperature difference. 
It can be seen that, due to the high concentration of water in the fuel reactor gas, further increased by spraying in the first scrubber, heat can be recovered at a comparatively high temperature level for condensing flue gas heat recovery. In terms of power plant steam cycle temperature levels, the temperature levels are still low, however, and there is a limited amount of low-temperature heat sinks available. To obtain more useful heat out of the scrubbing water stream, heat pumps are thus used. A coefficient of performance (COP) of 7.5 was assumed possible for a modern industrial heat pump obtaining a $20{ }^{\circ} \mathrm{C}$ temperature lift. With heat pumps, the clear majority of the district heat, approximately $75 \%$, can be produced from the recovered condensation heat, leaving only $25 \%$ to be produced in turbine condensers.

\subsubsection{Auxiliary Systems}

Auxiliary power consumption $P_{\text {aux }}$ in the reference plant was estimated by determining the steam cycle pump power consumptions from the IPSEpro model, and using a published figure of $11.9 \mathrm{MW}$ for all other auxiliary equipment in an operating CHP plant of same type of fuel, boiler capacity and similar configuration and power and heat generation [33].

The CLOU plant $P_{\text {aux }}$ was assumed to be similar to the reference plant except for the steam cycle pumps, boiler/reactor fans, heat pumps, and the $\mathrm{CO}_{2}$ compression and purification unit. The higher $\Delta p$ of the CLOU reactor system compared to the conventional CFB boiler of the reference plant requires an air blower with a pressure ratio of slightly over 1.3. In addition to the increased power consumptions, there is a temperature increase of approximately $30{ }^{\circ} \mathrm{C}$ at design point over both the air and flue gas recirculation fans. To consider these effects accurately, both the air and flue gas recirculation blowers are considered as components in the CLOU plant model. The power consumption of fuel and ash handling, and other pumps and fans not directly related to the boiler or steam cycle was assumed to remain similar to that of the reference plant, at approximately 2.9 MW according to Ikonen [33].

\section{Results}

\subsection{Overall Performance}

The main operating characteristics of the reference plant and the CLOU-CHP plant are listed in Table 3. At nominal load, the reference plant with conventional CFB boiler and $150{ }^{\circ} \mathrm{C}$ flue gas stack temperature has thermal output of $387 \mathrm{MW}$, and a net plant efficiency of $\eta_{\text {net }}=81.1 \%$. With the same fuel input, the CLOU system yields a $491 \mathrm{MW}$ thermal output, and $\eta_{\text {net }}=80.3 \%$. Although the CLOU plant has slightly reduced net efficiency, the increase of thermal power is considerable, explained by low-grade heat recovered mainly in the condensation of water from the fuel reactor gas, as well as to a lesser extent the low stack temperature of the air reactor gas flow. The benefit of condensing flue gas heat recovery is much less in conventional boilers, and such equipment is still uncommon in most operational large-scale plants, although recently they have started to appear in some new plants. For comparability such a scheme is also included, labeled "Ref. + FGC" in Table 3. The FGC-equipped variant of the reference plant uses the same two-stage heat recovery scheme, with the same heat sinks and same heat pump arrangement, temperature lift, and COP as in the CLOU system. At $448 \mathrm{MW}$ of thermal power, the conventional CFB boiler achieves only little over half of the thermal power gain from the FGC compared to the CLOU system.

The second law efficiencies of reference plants were compared by exergy analysis as described in Section 2.1. By considering the separated $\mathrm{CO}_{2}$ as a valuable product for later utilization, an exergetic efficiency of $42.0 \%$ was obtained for the CLOU plant, exceeding that of the reference plant without flue gas condensation (40.9\%) or only slightly less than with the FGC (42.2\%). Even if the exergy within the captured $\mathrm{CO}_{2}$ stream was not considered, the efficiency of $40.2 \%$ was close to the figures of the reference plants. The superior performance of the CLOU plant is mainly due to the high-temperature flue gas condensation, which provides a large share of the DH production in the CLOU plant. It is 
clear from the results that in CCS-equipped CHP plants, a large part of the exergy penalty from $\mathrm{CO}_{2}$ capture can be recovered by utilizing the heat from flue gas water condensation.

Figure 5 depicts the overall energy balance of both plants. It is evident that the main differences lie in the considerably smaller boiler losses, and greater turbine condenser loss, in the CLOU plant. The latter is a direct consequence of the former: based on the operating strategy of meeting the steam and $\mathrm{DH}$ demand, generating much of the district heat in the flue gas condensers leaves much more LP steam to be directed to the condensing turbine. The condensing turbine takes $54 \mathrm{~kg} / \mathrm{s}$ steam flow in the CLOU-CHP plant compared to $12 \mathrm{~kg} / \mathrm{s}$ in the reference case. The generator power is also clearly increased, but due to the considerable increase of auxiliary power consumption, net electricity production is still slightly reduced. The significant steam flow increase in the condensing turbine results in only a $19.6 \mathrm{MW}$ increase in generator power at design point, or $16.9 \%$ of the $105 \mathrm{MW}$ additional heat recovery. This is a result of the low pressure and temperature of the steam entering the condensing turbine; the live steam flow, with greater capacity for doing work, increases far less at only $5.1 \mathrm{~kg} / \mathrm{s}$.

Table 3. Main performance figures of the reference CHP plant and the CLOU equivalent.

\begin{tabular}{|c|c|c|c|c|}
\hline Category & Parameter & Reference & Ref. + FGC & CLOU \\
\hline \multirow{5}{*}{ Overall performance } & Fuel input (MW) & 430 & 430 & 430 \\
\hline & Thermal power (MW) & 387 & 448 & 492 \\
\hline & Net energy efficiency, LHV (\%) & 81.1 & 82.3 & 80.3 \\
\hline & Exergy efficiency $(\%)$ & 40.9 & 42.2 & 42 \\
\hline & w/o captured $\mathrm{CO}_{2}(\%)$ & 40.9 & 42.2 & 40.2 \\
\hline \multirow{6}{*}{ Ambient } & $\operatorname{Air} T\left({ }^{\circ} \mathrm{C}\right)^{1}$ & 25 & 25 & 39 \\
\hline & Stack $T\left({ }^{\circ} \mathrm{C}\right)$ & 150 & 58 & $69 / 58^{2}$ \\
\hline & Makeup water $T\left({ }^{\circ} \mathrm{C}\right)$ & 15 & 15 & 15 \\
\hline & Condenser coolant $T\left({ }^{\circ} \mathrm{C}\right)$ & 5 & 5 & 5 \\
\hline & DH supply $T\left({ }^{\circ} \mathrm{C}\right)$ & 90 & 90 & 90 \\
\hline & DH return $T\left({ }^{\circ} \mathrm{C}\right)$ & 45 & 45 & 45 \\
\hline \multirow{4}{*}{ Production } & Generator (MW) & 120.4 & 128.9 & 138.1 \\
\hline & Net electricity (MW) & 108.5 & 114 & 105.4 \\
\hline & District heat (MW) & 110 & 110 & 110 \\
\hline & Process steam (MW) & 130 & 130 & 130 \\
\hline \multirow{6}{*}{ Turbine } & HPT flow $(\mathrm{kg} / \mathrm{s})$ & 146.3 & 146.3 & 151.4 \\
\hline & DHT flow $(\mathrm{kg} / \mathrm{s})$ & 50.8 & 26.5 & 13.2 \\
\hline & DHT back pressure (bar) & 0.36 & 0.49 & 0.64 \\
\hline & CT swallowing capacity $(\mathrm{kg} / \mathrm{s})$ & 21 & 38.7 & 54.5 \\
\hline & CT flow $(\mathrm{kg} / \mathrm{s})$ & 12.2 & 38.7 & 54.5 \\
\hline & Condenser pressure (mbar) & 23 & 23 & 23 \\
\hline \multirow{2}{*}{ Condensers } & DH turbine (MW) & 110 & 57.9 & 28.4 \\
\hline & Vacuum condenser (MW) & 26.3 & 80.7 & 113.7 \\
\hline \multirow{6}{*}{ Auxiliary } & Fans and blowers (MW) & 6.5 & 6.5 & 7.2 \\
\hline & Steam cycle pumps (MW) & 2.5 & 2.6 & 2.7 \\
\hline & Heat pumps (MW) & - & 2.7 & 1.5 \\
\hline & $\mathrm{CO}_{2}-\mathrm{CPU}(\mathrm{MW})$ & - & - & 17.9 \\
\hline & Other (MW) & 2.9 & 3.6 & 3.5 \\
\hline & Total $P_{\text {aux }}(\mathrm{MW})$ & 11.9 & 15.3 & 32.7 \\
\hline \multirow{3}{*}{$\begin{array}{c}\mathrm{CO}_{2} \\
\text { emissions }\end{array}$} & Absolute (kg/s) & 46.7 & 46.7 & 1.3 \\
\hline & Specific $(\mathrm{kg} / \mathrm{MWh})^{3}$ & 482.4 & 482.1 & 13.2 \\
\hline & Negative $(\mathrm{t} / \mathrm{h})$ & - & - & 163.9 \\
\hline
\end{tabular}

${ }^{1}$ Temperature of air entering the air heaters, after the forced draft fan/blower. ${ }^{2}$ AR gas stack temperature/FR gas to $\mathrm{CO}_{2}$-CPU. ${ }^{3}$ Based on net production (electricity, $\mathrm{DH}$, and process steam).

The bulk of the increased auxiliary power consumption is due to the $\mathrm{CO}_{2}$ compression and purification unit, estimate to have a power consumption of $110 \mathrm{kWh} / \mathrm{t}_{\mathrm{CO} 2}$ based on [34], although the 
scrubber pumps and heat pumps also contribute to the increase by approximately $3 \mathrm{MW}$. Steam cycle pump and air and flue gas fan power consumptions are also slightly increased over those of the reference plant due to the increased steam cycle flow rate and increased pressure drop of the twin-CFB reactor system compared to the single CFB boiler of the reference plant. In contrast to the reference plant, more of the auxiliary equipment does work back into the system, however: not only the flue gas recirculation fan, but also the main flue gas fan before the heat recovery scrubbers leaves the majority of their power consumptions, except for the electromechanical losses, into the gas stream and available for use and recovery. Due to the greater pressure drop of the two reactors, the great majority of the pressure increase generated in the fans now takes place in the air fan; while this is not considered as work done into the system due to control volume boundary being set between air entry to the back pass air heaters and the forced draft fan or blower, it does show as increased energy input with the air.

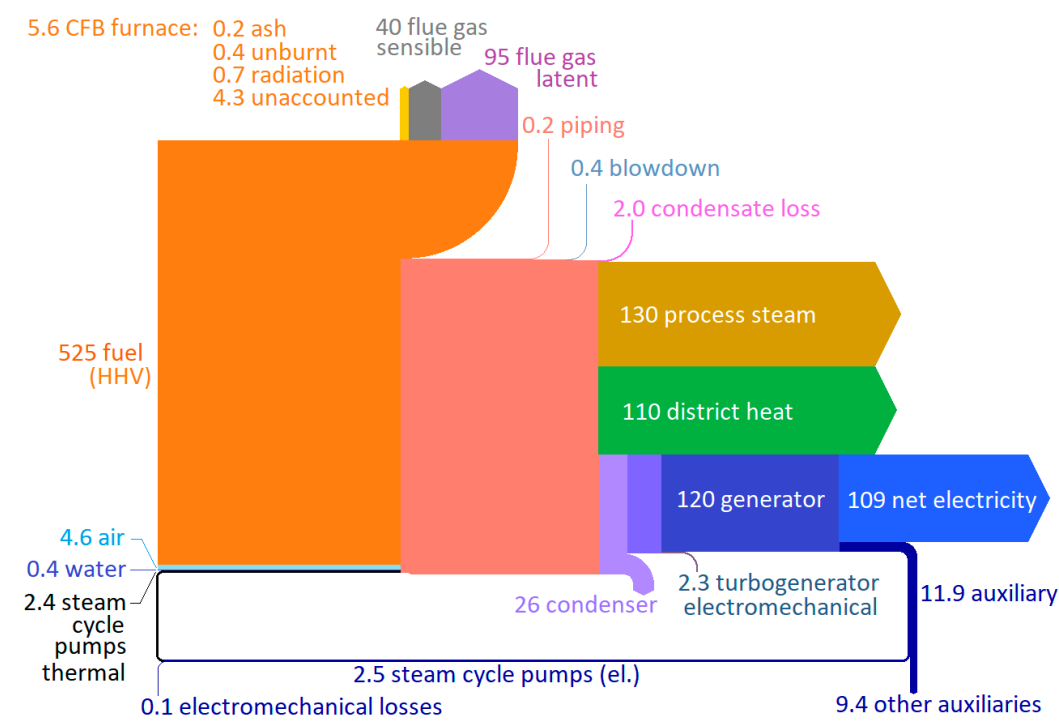

(a)

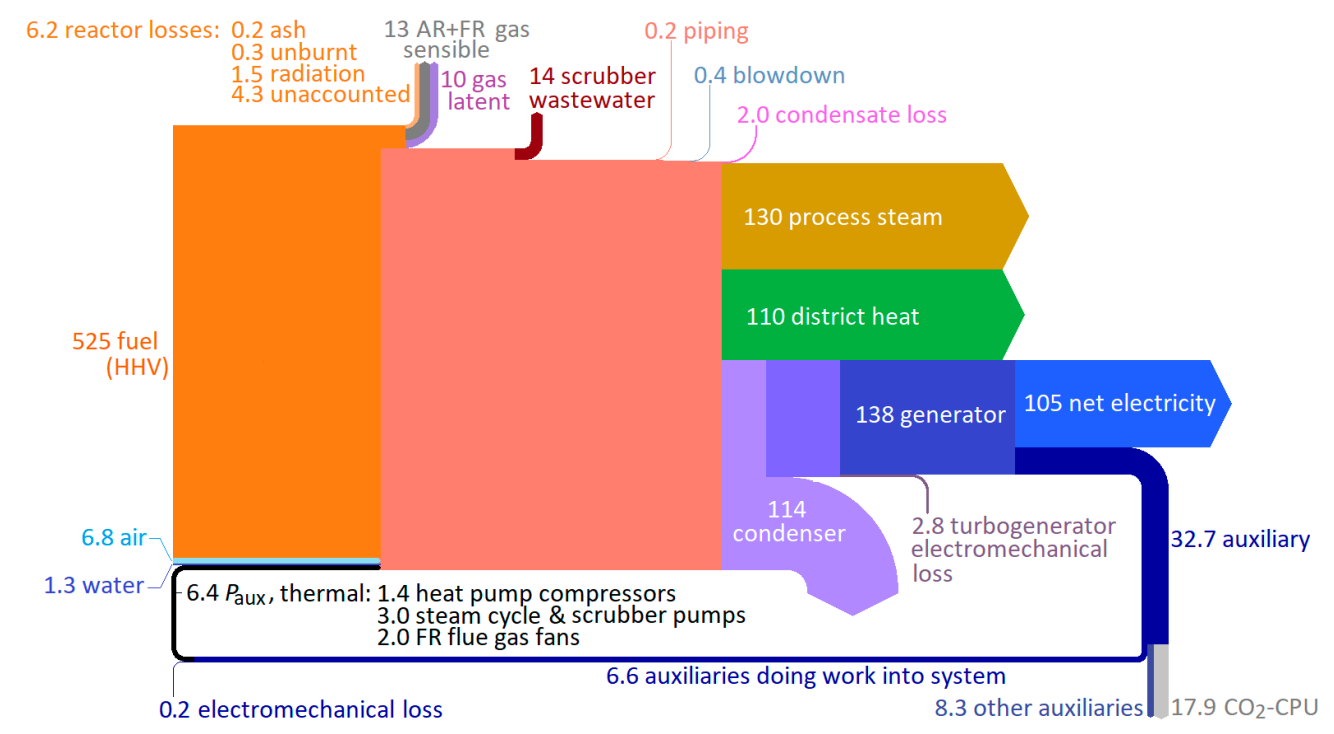

(b)

Figure 5. Sankey diagrams showing energy flows in: (a) reference plant; and (b) CLOU plant. Numbers represent energy flows (MW). The control volume is set at the entry of combustion air into air heaters; work by the forced draft fans is thus considered as a loss, while the enthalpy increase of the air in the fan or blower is considered in the energy entering the system. 


\subsection{Boiler and CLOU Reactor Convective Heat Transfer Surface Design}

Because the gas flow exiting the CLOU reactor system is split between the relatively clean and benign AR gas stream consisting mainly of oxygen-depleted air, and the FR gas stream with the combustion products including chlorine and alkalis at a higher concentration than in a conventional boiler flue gas, the design of the heat transfer surfaces also differs from the conventional boiler. The temperature diagrams of the reference plant and the CLOU system are shown in Figure 6.

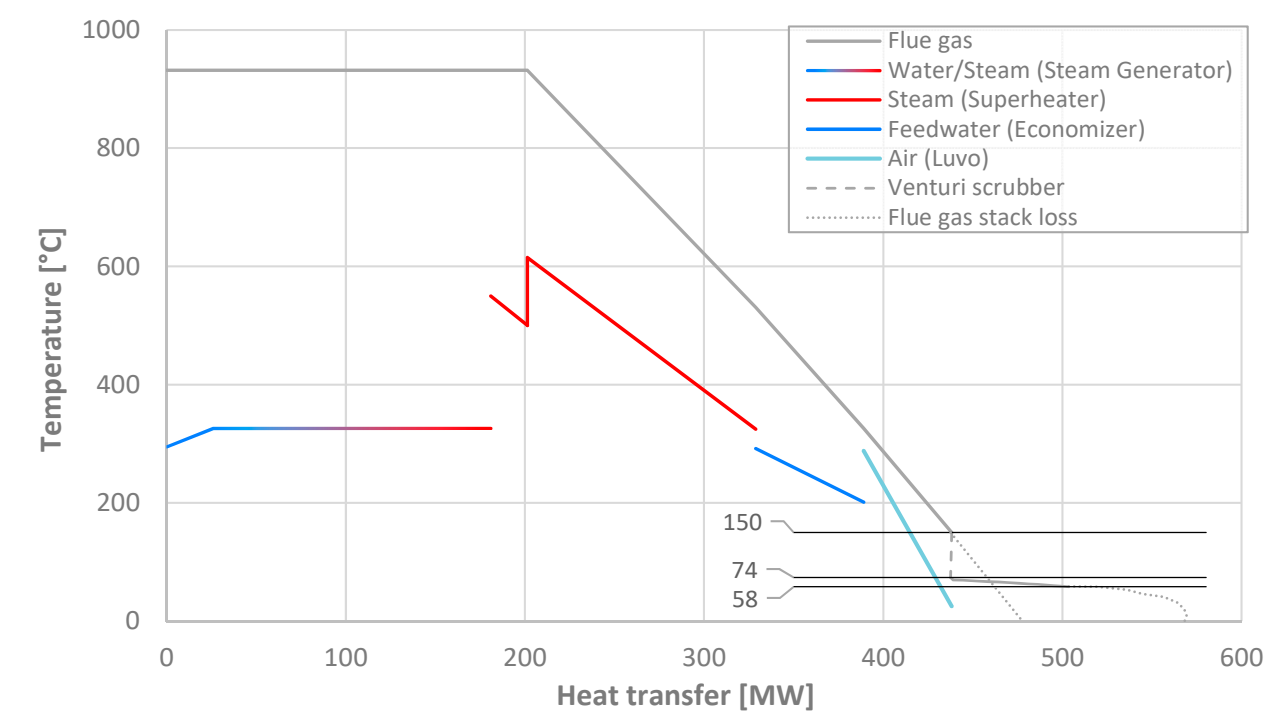

(a)

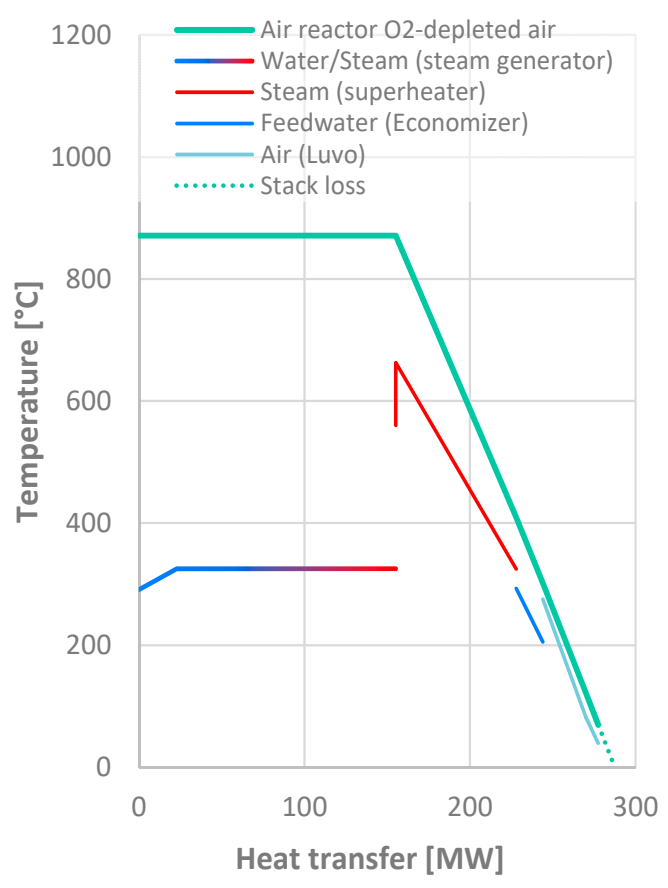

(b)

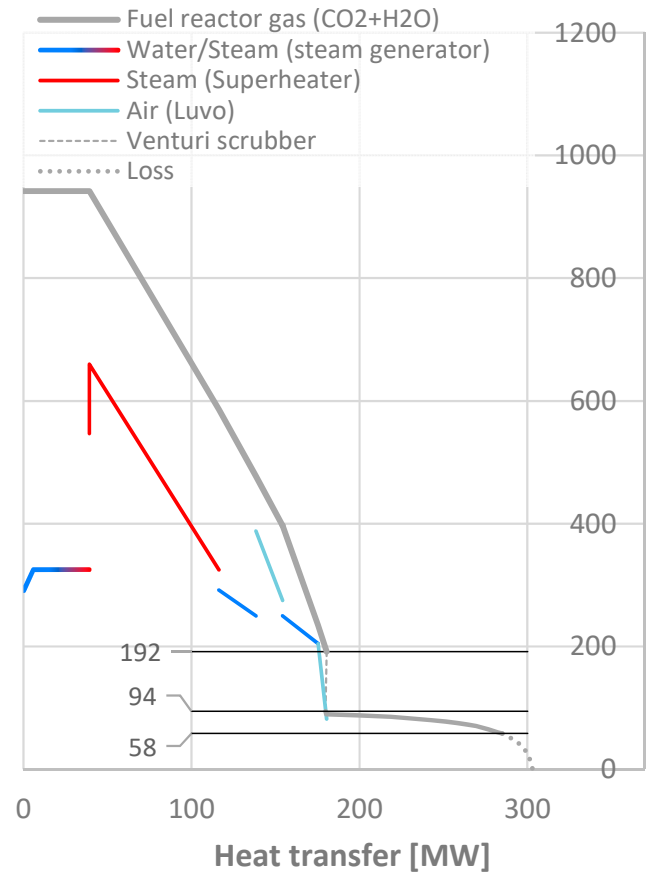

(c)

Figure 6. Temperature diagrams for: (a) reference plant; (b) CLOU air reactor; and (c) CLOU fuel reactor. The reference plant with or without flue gas condensation has identical back pass heat transfer surfaces; stack loss is shown both with and without flue gas condensation. The steam generator parts are not intended to be accurate representations of the temperature profiles, but only to depict the heat transfer rate and exit temperatures of gas and steam. 
Combustion air is passed first through the last air heater in the AR back pass; this is to ensure effective cooling of the AR flow, as well as to prevent condensation and corrosion risk in the final FR air heater by preheating the air. In the FR, gas is kept at $190^{\circ} \mathrm{C}$ before the flue gas condensers, and the air enters the final, coldest air heater at slightly over $80^{\circ} \mathrm{C}$ from the AR. The AR gas is cooled to a stack temperature of $69^{\circ} \mathrm{C}$.

The air intake is also arranged differently in the CLOU plant than in the reference plant: in a typical boiler, combustion air is usually taken from inside the boiler building, warmer than the ambient air. This yields an energy gain for little penalty, as the flue gas exit temperature from the last boiler surface is typically limited by acid condensation risk, not air temperature, and the forced draft fan pressure increase is small enough to render the penalty from compressing slightly warmer air negligible. Neither is true in the case of the CLOU system, however. The cooling of the air reactor gas, consisting mainly of nitrogen and excess oxygen, is practically limited by the availability of low-temperature heat sinks rather than corrosion risk; increasing the temperature of incoming air will thus increase the exit temperature of the AR gas, negating most of the heat gain. As the air blower for the CLOU system also has a pressure ratio of 1.32 , for a temperature increase of almost $30^{\circ} \mathrm{C}$ and a $5.2 \mathrm{MW}$ power consumption, an increased air temperature would also have a measurable impact on the auxiliary power consumption; thus, it is assumed that warm boiler room air is used for the conventional boiler, and colder ambient air for the CLOU air reactor.

The AR back pass heat exchangers are also designed for clearly smaller temperature differences than those of the FR back pass. While economic optimization was ruled beyond the scope of this study, it is clear that it would be the FR back pass where erosion, corrosion and fouling are expected to be worse problems, and more expensive materials will be needed. By maintaining a higher temperature difference in the FR, the required heat transfer area, and the metal temperature at the heat transfer surface, can both be reduced. The conductances $G(\mathrm{~kW} / \mathrm{K})$ required in each of the convective heat transfer surfaces are shown in Table 4 . It is evident that achieving the clearly lower gas exit temperatures in the air reactor requires also clearly higher conductances, and thus more heat transfer area.

Table 4. Convective heat transfer surface conductances in the reference plant boiler, and CLOU system air and fuel reactor back passes.

\begin{tabular}{cccc}
\hline Heat Transfer Surface & Reference CFB Boiler & CLOU Air Reactor & CLOU Fuel Reactor \\
\hline Superheater & $496 \mathrm{~kW} / \mathrm{K}$ & $525 \mathrm{~kW} / \mathrm{K}$ & $280 \mathrm{~kW} / \mathrm{K}$ \\
Economizer (hot) & $345 \mathrm{~kW} / \mathrm{K}$ & $150 \mathrm{~kW} / \mathrm{K}$ & $85 \mathrm{~kW} / \mathrm{K}$ \\
Economizer (cold) & $n / a$ & $n / a$ & $300 \mathrm{~kW} / \mathrm{K}$ \\
Air heater (hot) & $670 \mathrm{~kW} / \mathrm{K}$ & $800 \mathrm{~kW} / \mathrm{K}$ & $153 \mathrm{~kW} / \mathrm{K}$ \\
Air heater (cold) & $n / a$ & $150 \mathrm{~kW} / \mathrm{K}$ & $100 \mathrm{~kW} / \mathrm{K}$ \\
\hline
\end{tabular}

\subsection{Flue Gas Condensers}

Figure 6 shows also the performance of the flue gas condensers (FGC) of the FR exhaust, and in the reference plant if it were so fitted. The very slight move towards the left in the venturi scrubber is due to the heat input into the gas stream. This is due to the spray evaporation into the gas stream being slightly (less than $1 \mathrm{MW}$ in both cases) greater than the impact of reduced sensible enthalpy of the gas due to cooling. An outlet temperature of $58{ }^{\circ} \mathrm{C}$ is considered for both the FR gas FGC, and the conventional boiler one. The main limit in lowering the temperature is the availability of suitable low-temperature heat sinks, and the reducing COP of heat pumps if heat is transferred to a warmer heat sink over an increasingly high temperature lift. It can be seen that although the amount of water in the stream entering the VS and exit temperature are almost identical, due to the more concentrated water vapor in the FR gas exhaust stream, the clear majority of all water vapor can be condensed. In terms of remaining water, at $58^{\circ} \mathrm{C}$, only $4.5 \mathrm{~kg} / \mathrm{s}$ of water vapor remains in the FR stream. If the FGC were to be installed in the reference plant, however, at $58^{\circ} \mathrm{C}$ the flue gas would still contain $25 \mathrm{~kg} / \mathrm{s}$ of 
water, i.e., the FGC could only condense approximately $1 / 3$ of the water vapor introduced from fuel moisture and hydrogen.

The much reduced heat gain available from the more diluted flue gas stream in a conventional boiler is the main reason the benefit of installing an FGC in a conventional boiler would be much less than in the CLOU plant: $8.5 \mathrm{MW}$ generator power increase, or $13.8 \%$ of a $61 \mathrm{MW}$ thermal power gain.

\subsection{Carbon Capture Performance}

The CLOU reactor system showed high performance with the wood biomass fuel; the volatile matter that was generated during devolatilization was almost completely converted to $\mathrm{CO}_{2}$ and $\mathrm{H}_{2} \mathrm{O}$. Only a minor fraction of the char remained unburnt and escaped to the air reactor, resulting in a total $\mathrm{CO}_{2}$ capture efficiency of $97 \%$. Most of the char escaping to the air reactor burned there, and unburned losses were low.

The specific $\mathrm{CO}_{2}$ emissions from the CLOU plant were very low in comparison to those of the reference plant: $13 \mathrm{~kg}_{\mathrm{CO} 2} / \mathrm{MWh}$ versus $482 \mathrm{~kg}_{\mathrm{CO}} / \mathrm{MWh}$. The specific negative $\mathrm{CO}_{2}$ emissions from the CLOU plant, defined as the ratio of potential $\mathrm{CO}_{2}$ removal rate from the atmosphere and net plant production (electricity + heat), was found to be approximately $470 \mathrm{~kg}_{\mathrm{CO} 2} / \mathrm{MWh}$.

\section{Discussion}

The CLOU scheme presented above proved to result in a highly effective $\mathrm{CO}_{2}$ capture process, with only a very small efficiency penalty of $0.7 \%$. The low efficiency penalty is particularly noteworthy as it was achieved while shifting the steam cycle operation from mainly back pressure plant towards a condensing one, in a plant with modest live steam pressure and no reheat; this alone without the added parasitic load of the $\mathrm{CO}_{2}$ capture could be expected to clearly reduce the net efficiency. The low efficiency penalty is in large part due to the efficient waste heat recovery system, as well as the comparatively low parasitic load of chemical looping combustion based CCS systems.

The CLOU heat recovery scheme yields an additional $105 \mathrm{MW}$ of low-grade heat from the same $430 \mathrm{MW}_{\mathrm{LHV}}$ fuel input as used in the reference plant, corresponding to a $27 \%$ increase over the conventional reference plant. Although the low-grade heat enables only an additional $18 \mathrm{MW}$ of gross power generation, this is enough to almost offset the additional parasitic load caused by the CCS scheme. The effective heat recovery is made possible by the way the CLOU system separates the exhaust gas flow into two streams: one with the oxygen-depleted air, and the other with undiluted combustion products. This increases both the heat recovery temperature and the fraction of the flue gas moisture that can be condensed, as well as enabling the oxygen-depleted air to be cooled to a lower temperature without low-temperature corrosion risk.

While still relatively uncommon, such a heat recovery scheme could also be added to a conventional boiler. The approximately $16 \%$ of additional heat recovery achieved in the reference plant falls in the range of typical values obtained for biomass-fired boilers in an earlier study considering heat-only boilers [35]. In the CHP plant studied here, the DH return water could be heated only by approximately $20{ }^{\circ} \mathrm{C}$ by condensing heat recovery from conventional CFB boiler flue gas. With the $5.5 \mathrm{MW}$ additional net power generation from flue gas condensation, the advantage of the reference case over the CLOU plant would grow to $8.6 \mathrm{MW}$ of net power generation and $2 \%$ of net efficiency. This, too, is still a very low figure for performance loss caused by a carbon capture solution. The efficiency loss amounts to an order of magnitude less than what was recently obtained for industrial steam cycle CHP BECCS implementation based on conventional post-combustion amine scrubbing CCS technology [36]. Even though the comparability of the results is limited due to the different configurations of the plants, the magnitude of the difference gives a strong indication of a considerable efficiency advantage in favor of the CLOU technology.

Calcium looping (CaL) and oxy-combustion technologies are other alternatives for BECCS, sharing some advantages with chemical looping, but also with notable differences. Oxy-combustion, as the name suggests, involves burning the fuel with oxygen instead of air. This yields a flue gas stream not 
diluted with nitrogen, very similar to the FR gas stream from the CLOU reactor system. CaL, on the other hand, is a post-combustion technology, where the combustor resembling a conventional boiler is followed by a twin-reactor system of calciner and carbonator. This, too, yields a stream with more concentrated water vapor from the calciner. One clear disadvantage is that, with separate combustor, calciner, and carbonator, three CFB reactors are required.

Another disadvantage of particularly the oxy-combustion, but to some extent also CaL, is the requirement for oxygen. Producing the oxygen requires an air separation unit, which introduces a significant additional parasitic load. Recently, calcium looping and oxy-combustion were compared for CHP generation in a plant only slightly larger than the one considered in this study [37]. Although the plant differs from the one considered here enough to make direct comparisons of results infeasible, the impact of the air separation unit on the parasitic load becomes clear: in oxy-combustion the magnitude is broadly similar to that of the $\mathrm{CO}_{2}-\mathrm{CPU}$, and in $\mathrm{CaL}$, approximately half of it.

During the last ten years, a firm base has been achieved in the development of chemical looping processes for solid fuels, including experience gained from experimental chemical looping units ranging from 0.5 to $4 \mathrm{MW}_{\text {th }}$ [6]. The CLOU reactor system presented in this paper has significant similarities with the well-known and commercially available CFB combustion technology for solid fuels. Thus, retrofitting a circulating fluidized bed with chemical looping by adding two reactors side by side can be seen as a promising option in the next stage of the scale-up process.

\section{Conclusions}

The studied system appears to offer an efficient pathway to utilize biomass resources in a sustainable and efficient manner while removing $\mathrm{CO}_{2}$ (net) from the atmosphere. A very small net efficiency penalty of less than $1 \%$ point was achieved in comparison to the conventional reference plant operating with the same fuel input and the same heat production, even though the CLOU plant operation was shifted from mostly back pressure towards inherently less efficient condensing cycle.

The good performance was mainly due to two reasons. Firstly, the CLOU system provides an opportunity for highly efficient heat recovery due to the separate streams of combustion products and oxygen-depleted air. Secondly, the parasitic load of the CCS scheme is low, limited to the unavoidable $\mathrm{CO}_{2}$ compression and purification unit and a fairly modest increase of fan power and heat recovery system power consumption. There is no need for solvent regeneration or producing oxygen in an air separation unit, which typically introduce significant heat or power demands in alternative CCS solutions.

Based on the results presented in this study, the overall performance of CLOU-based BECCS schemes is considered potentially superior to many alternatives, but definitive conclusions cannot be drawn yet based on these initial results. Further studies are required to develop a better understanding of the advantages and disadvantages of alternative technologies, and to evaluate the suitability for different applications with different heat consumers, as well as different plant configurations. Furthermore, the successful implementation of $\mathrm{CO}_{2}$ capture technologies in the power and heat sector will depend not only on the technical performance, but also on the economics. Future work will include a detailed economic analysis of the proposed CLOU-CHP plant, as well as considering seasonal variations in DH load and temperature levels.

Author Contributions: Conceptualization, J.S. and P.P.; methodology, J.S. and P.P.; software, J.S. and P.P.; investigation, J.S., P.P. and T.T.; writing —original draft preparation, J.S., P.P. and T.T.; writing—review and editing, J.K., P.P, T.T., E.V. and T.H.; visualization, J.S.; and funding acquisition, P.P. All authors have read and agreed to the published version of the manuscript.

Funding: This research was partially funded by Academy of Finland, grant number 297485.

Conflicts of Interest: The authors declare no conflict of interest. The funders had no role in the design of the study; in the collection, analyses, or interpretation of data; in the writing of the manuscript, or in the decision to publish the results. 


\section{Nomenclature}

Abbreviations

AR Air reactor

BECCS Bioenergy with $\mathrm{CO}_{2}$ capture and storage

$\mathrm{CaL} \quad$ Calcium looping

CCS $\quad \mathrm{CO}_{2}$ capture and storage

CFB Circulating fluidized bed

CHP Combined heat and power

CLC Chemical-looping combustion

CLOU Chemical-looping combustion with oxygen uncoupling

COP Coefficient of power

CPU Compression and purification unit

CT Condensing turbine

$\mathrm{DH} \quad$ District heating

DHT District heat turbine

FGC Flue gas condenser

FR Fuel reactor

GS Governing stage

HP High pressure

$\mathrm{HPPH} \quad$ High pressure feed preheater

HPT High pressure turbine

HRS Heat recovery scrubber

$i$ G-CLC in-situ gasification chemical looping combustion

LHV Lower heating value

LP Low pressure

NET Negative emission technology

OC Oxygen carrier

$\mathrm{SH} \quad$ Superheater

VC Vacuum condenser

VS Venturi scrubber

Variables (Greek)

$b \quad$ Reaction order (-)

$\varphi \quad$ Exergy efficiency (\%)

$F \quad$ Heat rate; thermal power (W)

$h \quad$ Efficiency (\%)

$r \quad$ Density $\left(\mathrm{kg} / \mathrm{m}^{3}\right)$

Variables (Latin)

$c_{\mathrm{p}} \quad$ Specific heat $(\mathrm{J} / \mathrm{kgK})$

[C] Mass fraction of carbon (-)

$D_{\mathrm{AB}} \quad$ Mass diffusivity $\left(\mathrm{m}^{2} / \mathrm{s}\right)$

Ex Exergy rate (W)

$G \quad$ Conductance (product of area and overall heat transfer coefficient) $(\mathrm{kW} / \mathrm{K})$

$h_{\mathrm{fg}} \quad$ Latent heat of evaporation $(\mathrm{kJ} / \mathrm{kg})$

DH Reaction enthalpy $(\mathrm{kJ} / \mathrm{mol})$

I Irreversibility (rate of exergy destruction) (W)

$k \quad$ Thermal conductivity $(\mathrm{W} / \mathrm{mK})$

$k_{1} \quad$ Pre-exponential factor $(1 /(\mathrm{atm} \mathrm{s}))$

$k_{2} \quad$ Activation energy $(\mathrm{J} / \mathrm{mol})$

Le Lewis number (ratio of thermal diffusivity to mass diffusivity) (-)

$\dot{m} \quad$ Mass flow rate $(\mathrm{kg} / \mathrm{s})$

$M_{\mathrm{H} 2 \mathrm{O}} \quad$ Molar mass of water, $18.015 \mathrm{~kg} / \mathrm{kmol}$

$P \quad$ Power (W)

p Pressure (Pa); (bar); (atm) 


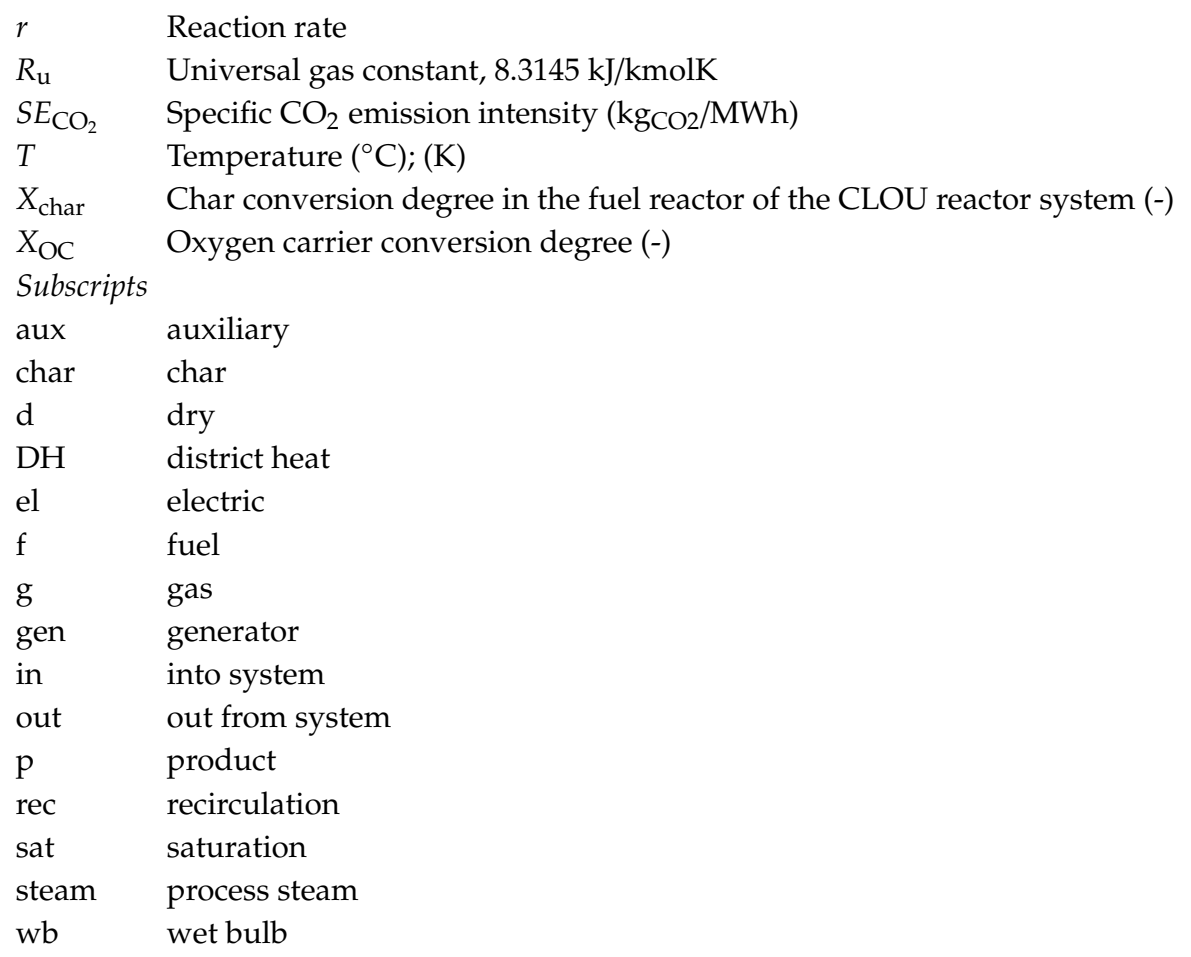

\section{References}

1. IPCC. IPCC Climate Change 2014: Synthesis Report. Contribution of Working Groups I, II and III to the Fifth Assessment Report of the Intergovernmental Panel on Climate Change; IPCC: Geneva, Switzerland, 2014.

2. IPCC. Summary for policymakers. In Global Warming of $1.5^{\circ} \mathrm{C}$; An IPCC Special Report on the Impacts of Global Warming of $1.5^{\circ} \mathrm{C}$ above Pre-Industrial Levels and related Global Greenhouse Gas Emission Pathways, in the Context of Strengthening the Global Response to the Threat of Climate Change, Sustainable Development, and Efforts to Eradicate Poverty; IPCC: Geneva, Switzerland, 2018; p. 32.

3. Fuss, S.; Lamb, W.F.; Callaghan, M.W.; Hilaire, J.; Creutzig, F.; Amann, T.; Beringer, T.; De Oliveira Garcia, W.; Hartmann, J.; Khanna, T.; et al. Negative emissions-Part 2: Costs, potentials and side effects. Environ. Res. Lett. 2018, 13, 063002. [CrossRef]

4. Cuellar, A.D.; Herzog, H. A Path Forward for Low Carbon Power from Biomass. Energies 2015, 8, $1701-1715$. [CrossRef]

5. Gibbins, J.; Chalmers, H. Carbon capture and storage. Energy Policy 2008, 36, 4317-4322. [CrossRef]

6. Adánez, J.; Abad, A.; Mendiara, T.; Gayán, P.; De Diego, L.F.; García-Labiano, F. Chemical looping combustion of solid fuels. Prog. Energy Combust. Sci. 2018, 65, 6-66. [CrossRef]

7. Sifat, N.S.; Haseli, Y. A critical review of $\mathrm{CO}_{2}$ capture technologies and prospects for clean power generation. Energies 2019, 12, 4143. [CrossRef]

8. Lyngfelt, A.; Leckner, B.; Mattisson, T. A fluidized-bed combustion process with inherent $\mathrm{CO}_{2}$ separation; application of chemical-looping combustion. Chem. Eng. Sci. 2001, 56, 3101-3113. [CrossRef]

9. Adánez, J.; Abad, A. Chemical-looping combustion: Status and research needs. Proc. Combust. Inst. 2019, 37, 4303-4317. [CrossRef]

10. Mattisson, T. Materials for chemical-looping with oxygen uncoupling. ISRN Chem. Eng. 2013, $2013,526375$. [CrossRef]

11. Peltola, P.; Ritvanen, J.; Tynjälä, T.; Hyppänen, T. Fuel reactor modelling in chemical looping with oxygen uncoupling process. Fuel 2015, 147, 184-194. [CrossRef]

12. Spinelli, M.; Peltola, P.; Bischi, A.; Ritvanen, J.; Hyppänen, T.; Romano, M.C. Process integration of chemical looping combustion with oxygen uncoupling in a coal-fired power plant. Energy 2016, 103, 646-659. [CrossRef]

13. Kevat, M.D.; Banerjee, T. Process simulation and energy analysis of chemical looping combustion and chemical looping with oxygen uncoupling for sawdust biomass. Energy Technol. 2018, 6, 1237-1247. [CrossRef] 
14. Statistics Finland. Energy in Finland. 2018. Available online: http://www.stat.fi/tup/julkaisut/tiedostot/ julkaisuluettelo/yene_efp_201800_2018_19368_net.pdf (accessed on 4 October 2019).

15. Peltola, P.; Ritvanen, J.; Tynjälä, T.; Pröll, T.; Hyppänen, T. One-dimensional modelling of chemical looping combustion in dual fluidized bed reactor system. Int. J. Greenh. Gas Control 2013, 16, 72-82. [CrossRef]

16. Bolhar-Nordenkampf, J.; Pröll, T.; Kolbitsch, P.; Hofbauer, H. Comprehensive modeling tool for chemical looping based processes. Chem. Eng. Technol. 2009, 32, 410-417. [CrossRef]

17. Saari, J.; Carvalho, M.M.; Sermyagina, E.; Vakkilainen, E.; Kaikko, J. Optimization of a shell-and-tube district heat condenser for a small back pressure combined heat and power plant. In Proceedings of the 12th International Conference on Heat Transfer, Fluid Dynamics and Thermodyn (HEFAT 2016), Malaga, Spain, 11-13 July 2016.

18. Gładysz, P.; Saari, J.; Czarnowska, L. Thermo-ecological cost analysis of cogeneration and polygeneration energy systems-Case study for thermal conversion of biomass. Renew. Energy 2020, 145, 1748-1760. [CrossRef]

19. Atsonios, K.; Panopoulos, K.; Grammelis, P.; Kakaras, E. Exergetic comparison of $\mathrm{CO}_{2}$ capture techniques from solid fossil fuel power plants. Int. J. Greenh. Gas Control 2016, 45, 106-117. [CrossRef]

20. Luo, M.; Yi, Y.; Wang, C.; Liu, K.; Pan, J.; Wang, Q. Energy and exergy analysis of power generation systems with chemical looping combustion of coal. Chem. Eng. Technol. 2018, 41, 776-787. [CrossRef]

21. Peltola, P.; Tynjälä, T.; Ritvanen, J.; Hyppänen, T. Mass, energy, and exergy balance analysis of chemical looping with oxygen uncoupling (CLOU) process. Energy Convers. Manag. 2014, 87, 483-494. [CrossRef]

22. Clayton, C.K.; Sohn, H.Y.; Whitty, K.J. Oxidation kinetics of $\mathrm{Cu}_{2} \mathrm{O}$ in oxygen carriers for chemical looping with oxygen uncoupling. conversion to fuels. Ind. Chem. Eng. Res. 2014, 53, 2976-2986. [CrossRef]

23. Clayton, C.K.; Whitty, K.J. Measurement and modeling of decomposition kinetics for copper oxide-based chemical looping with oxygen uncoupling. Appl. Energy 2014, 116, 416-423. [CrossRef]

24. Peltola, P.; Ritvanen, J.; Tynjälä, T.; Hyppänen, T. Model-based evaluation of a chemical looping combustion plant for energy generation at a pre-commercial scale of 100 MWth. Energy Convers. Manag. 2013, 76, 323-331. [CrossRef]

25. Mattisson, T.; Keller, M.; Linderholm, C.; Moldenhauer, P.; Rydén, M.; Leion, H.; Lyngfelt, A. Chemical-looping technologies using circulating fluidized bed systems: Status of development. Fuel Process. Technol. 2018, 172, 1-12. [CrossRef]

26. Abad, A.; Adánez-Rubio, I.; Gayán, P.; García-Labiano, F.; De Diego, L.F.; Adánez, J. Demonstration of chemical-looping with oxygen uncoupling (CLOU) process in a $1.5 \mathrm{~kW}$ th continuously operating unit using a Cu-based oxygen-carrier. Int. J. Greenh. Gas Control 2012, 6, 189-200. [CrossRef]

27. Marx, K.; Bolhàr-Nordenkampf, J.; Pröll, T.; Hofbauer, H. Chemical looping combustion for power generation-Concept study for a $10 \mathrm{MWth}$ demonstration plant. Int. J. Greenh. Gas Control 2011, 5, 1199-1205. [CrossRef]

28. Mendiara, T.; Abad, A.; Gayán, P.; De Diego, L.F.; Izquierdo, M.T.; Adánez, J. Negative $\mathrm{CO}_{2}$ emissions through the use of biofuels in chemical looping technology: A review. Appl. Energy 2018, 232, 657-684. [CrossRef]

29. Whitty, K. Practical design challenges for a CLOU-based system for chemical looping combustion of coal. In Proceedings of the 2nd International Conference on Chemical Looping, Darmstadt, Germany, 26-28 September 2012.

30. Saari, J.; Kuparinen, K.; Sermyagina, E.; Vakkilainen, E.K.; Kaikko, J.; Sergeev, V. Effect of integration method and carbonization temperature on the performance of an integrated hydrothermal carbonization and CHP plant. BioResources 2018, 13, 5080-5110.

31. Basu, P. Combustion and Gasification in Fluidized Bed, 1st ed.; CRC Press, Taylor \& Francis Group: Boca Raton, FL, USA, 2006.

32. Veidenbergs, I.; Blumberga, D.; Vigants, E.; Kozuhars, G. Heat and mass transfer processes in scrubber of flue gas heat recovery device. Sci. J. Riga Tech. Univ. Environ. Clim. Technol. 2010, 4, 109-115. [CrossRef]

33. Ikonen, O. Improving Energy Efficiency of Biomass Power Plant and Optimizing Partial-Load Operation (in Finnish: Biovoimalaitoksen Energiatehokkuuden Parantaminen ja Osakuorma-Ajon Optimointi). Master's Thesis, Lappeenranta University of Technology, Lappeenranta, Finland, 2013.

34. Aspelund, A.; Kristin, J. Gas conditioning-The interface between $\mathrm{CO}_{2}$ capture and transport. Int. J. Greenh. Gas Control 2007, 1, 343-354. [CrossRef] 
35. Hebenstreit, B.; Schnetzinger, R.; Ohnmacht, R.; Höftberger, E.; Lundgren, J.; Haslinger, W.; Toffolo, A. Techno-economic study of a heat pump enhanced flue gas heat recovery for biomass boilers. Biomass Bioenergy 2014, 71, 12-22. [CrossRef]

36. Restrepo-Valencia, S.; Walter, A. Techno-economic assessment of bio-energy with carbon capture and storage systems in a typical sugarcane mill in Brazil. Energies 2019, 12, 1129. [CrossRef]

37. Parkkinen, J.; Korpinen, T.; Tynjälä, T.; Sormunen, R.; Hyppänen, T. The post-combustion calcium looping process integrated with CHP plant. In Proceedings of the 22nd International Conference on Fluidized Bed Conversion (FBC), Turku, Finland, 14-17 June 2015.

(C) 2020 by the authors. Licensee MDPI, Basel, Switzerland. This article is an open access article distributed under the terms and conditions of the Creative Commons Attribution (CC BY) license (http://creativecommons.org/licenses/by/4.0/). 